\title{
Macauba production estimated by regression models
}

\section{Estimativas de produção de macaúba por modelos de regressão}

\author{
Juaci Vitoria MALAQUIAS ${ }^{1}$; Léo Duc Haa Carson Schwartzhaupt da CONCEIÇÃO² \\ Marcelo Fideles BRAGA ${ }^{3}$; Nilton Tadeu Vilela JUNQUEIRA ${ }^{4}$ \\ ${ }^{1}$ Mestre, Embrapa Cerrados, e-mail: juaci.malaquias@embrapa.br \\ ${ }^{2}$ Autor para correspondência Doutor, Embrapa Cerrados, Núcleo de Produção Vegetal, BR 020 Km 18, Caixa Postal 08223 , \\ Planaltina-DF, 73310-970 Fone +55(61) 3388-9898, Fax +55(61) 3388-9879, e-mail: leo.carson@embrapa.br \\ ${ }^{3}$ Doutor, Embrapa Cerrados, e-mail: marcelo.fideles@embrapa.br \\ ${ }^{4}$ Doutor, Embrapa Cerrados, e-mail: nilton.junqueira@embrapa.br
}

Recebido em: 25-04-2019; Aceito em: 29-07-2019

\begin{abstract}
Macauba has been shown to be the most promising native species for oil and biomass production. The first commercial crops have arisen mainly in Minas Gerais State, and estimates indicate a vegetable oil yield potential above $8 \mathrm{t} \mathrm{ha}^{-1}$. In this context, research has acted strongly on technological advance for improvements in the production system and selection of superior genotypes, which requires the use of precise and less expensive methodologies. Thus, we built prediction models to estimate the weight of macauba bunches using easy-to-measure physical variables. Bunches of plants from five regions of Brazil were evaluated. The bunches were weighed, and length and diameter were measured along with four other variables. Based on the set of variables obtained, stepwise multiple regression analysis was used to build regression models for each region. The correlation between observed versus estimated data reached determination coefficients $\left(R^{2}\right)$ above 0.90 in three of the models built. The main variables selected by the best models were bunch volume, bunch length/diameter ratio, and bunch square diameter.
\end{abstract}

Additional keywords: Acrocomia aculeata; agroenergy; oil yield; stepwise.

\section{Resumo}

A macaúba tem sido apontada como a mais promissora das espécies nativas para produção de óleo e biomassa. Estimativas indicam o potencial produtivo acima de $8 \mathrm{tha}^{-1}$ de óleo vegetal, e os primeiros cultivos comerciais têm surgido, principalmente, no Estado de Minas Gerais. Neste contexto, a pesquisa tem atuado fortemente para o avanço tecnológico para melhorias do sistema de produção e seleção de genótipos superiores, sendo necessário o uso de metodologias precisas e menos onerosas. Assim sendo, objetivou-se construir modelos de predição para a estimativa do peso de cachos em macaubeira, por meio de caracteres físicos de fácil mensuração. Foram realizadas avaliações em cachos de plantas originadas de cinco regiões do Brasil. Os cachos foram pesados, e foram medidos o comprimento e o diâmetro e, posteriormente, calculadas outras quatro variáveis. Com base no conjunto de variáveis obtidas, foi empregada análise de regressão múltipla, stepwise, para construção de modelos de regressão para cada região. A correlação entre os dados observados versus estimados alcançou coeficientes de determinação $\left(R^{2}\right)$ acima de 0,90 em três dos modelos construídos. As principais variáveis selecionadas pelos melhores modelos foram volume de cacho, produto do comprimento e do diâmetro do cacho e quadrado do diâmetro do cacho.

Palavras-chave adicionais: Acrocomia aculeata; rendimento de óleo; stepwise; agroenergia.

\section{Introduction}

Soybean is currently the main raw material for biodiesel production in Brazil. However, several other oilseeds have been used and many Brazilian native species have been studied as alternative sources (Nass et al., 2007). These research efforts are mainly justified by socioenvironmental reasons in the search for options with higher yield per area, thus more suitable for family farming, with better energy balance and higher carbon fixation rate. Macauba (Acrocomia aculeata (Jacq.) Lodd. Ex Mart.), a native palm of the Cerrado biome, stands out as an alternative oil source and raw material for biofuels due to its yield potential and oil quality (Lopes et al., 2013; Lanes et al., 2014; César et al., 2015; Cardoso et al., 2016). This plant is considered as the most promising among Brazilian native species in the search for new alternative oilseeds (Conceição et al., 2015), which is justified by the diversity of possible and potential coproducts and the use of its residues. Macauba can be used for charcoal production (Evaristo et al., 2016), human food (Hiane et al., 2005; Hiane et al., 2006; Ramos et al., 2008), animal feed (Rufino et al., 2011; Azevedo et al., 2012; Fonseca et al., 2012), and in the production of drugs (Lescano et al., 2015) and cosmetics (Callegari, 2015). 
Knowledge about this species and technological advance for its applications have increased a lot lately. Research on population assessments and fieldcontrolled experiments has been carried out. However, designs that involve the evaluation of a large number of plants and the difficulties inherent to species peculiarities (plant height, unevenness of maturation between bunches, and large amount of thorns), besides limited financial resources, encourage the use of alternative methodologies. The solution to circumvent the difficulty of evaluating macauba fruit production may be the construction and use of biometric models that involve easily accessible and measurable morphological characteristics, based on the allometric relationship between the character and the variable of interest.

There are several studies based on biometric models or allometric relationships that make use of multiple regression equations, which through morphological characters estimate yield, product or coproduct biomass, or yield components. Examples are found in other palm species such as pupunha (Vega et al., 2004) and carnauba (Silva et al., 2015), and in traditional perennial fruit such as banana (Zucoloto et al., 2013) and mango (Castro Neto \& Reinhardt, 2003; Morais et al., 2004).

The concept of allometry applies in studies where there is a scale relationship between the different morphological components of a given organism (Klingenberg \& Nijhout, 2016; Mirth et al., 2016), in which characteristics of the relative dimensions of parts of an organism are correlated with the characteristics of shape and total size (Moraes, 2015). Tabachnick and Fidell (1996) define multiple regression as a statistical method that allows the evaluation of the relationship of a dependent variable with several independent variables. The equation generated by multiple regression represents an additive model to explain and predict the variable of interest from several predictor variables (Abbad \& Torres, 2002). Based on these principles, we built biometric models for different macauba populations to estimate bunch weight.

\section{Materials and methods}

Plant populations from five regions (Montes Claros; Alto Paranaíba; Lavras region, Minas Gerais State; Formosa region, Goiás State; and Distrito Federal) were evaluated (Table 1). Mature macauba bunches were evaluated in situ. The bunches were harvested, and the following field variables were observed with the help of a measuring tape and a suspended digital scale: bunch length (BL), bunch diameter (BD), and bunch weight (BW). The following variables were also calculated: bunch volume $\left(B V=\pi^{*}(B D / 2)^{2 *} B L\right)$, bunch length-diameter ratio $\left(B L D=B L^{*} B D\right)$, square bunch length $\left(S B L=B L^{2}\right)$, and square bunch diameter $\left(\mathrm{SBD}=\mathrm{BD}^{2}\right)$.

Table 1 - Origin of Macauba populations, sampling locations for bunches evaluation and number of bunches observed.

\begin{tabular}{lllr}
\hline Federative unit & \multicolumn{1}{c}{ Region } & Collection municipalities & $\begin{array}{c}\text { Number of } \\
\text { bunches }\end{array}$ \\
\hline & 1 - Montes Claros & Mirabela & 10 \\
State of Minas Gerais & & São Gotardo & 5 \\
& 2 - Alto Paranaíba & Carmo do Paranaíba & 15 \\
\cline { 2 - 4 } & & Córrego Danta & 8 \\
\hline Federal district & 3 - Lavras & Ingaí & 5 \\
\hline State of Goiás & 4 - Distrito Federal & Núcleo Rural Buriti Vermelho & 11 \\
\hline
\end{tabular}

Exploratory analysis made it possible to verify the existence of possible outliers through standardized residuals greater than +2 or less than -2 . Analysis of variance was used to evaluate the multiple linear regression model by the least squares method. The t-test evaluated the statistical significance of the regression coefficients estimated in each model at a significance level of $5 \%$. The quantile-quantile (QQ) plot was used to assess the assumption of normality in the models. The fit quality of the model was evaluated by the coefficient of determination $\left(R^{2}\right)$. The multicollinearity assumption was also verified when in the presence of a high correlation between explanatory variables, that is, between two or more independent variables included in the model, a problem which may impact the estimation of model parameters. Therefore, multicollinearity was assessed by Pearson's linear correlation coefficient and variance inflation factor (VIF). With these procedures, the four regression assumptions (linearity, error independence, error normality, and equality of variance) were evaluated (Santana et al., 2015).

The stepwise procedure was used to identify the potential variables for the multiple linear regression model. This procedure is based on the construction of models by adding or removing variables, using variables correlated with the response variable. For the entry and permanence of potential variables in the model, the significance level of $5 \%$ was adopted as the criterion to estimate the variable of interest (dependent variable). The multiple linear regression equation is given by:

$y_{i}=\beta_{0}+\beta_{1} x_{i 1}+\beta_{2} x_{i 2}+\cdots+\beta_{k} x_{i k}+\varepsilon_{i}(i=1, \ldots, n)$

wherein:

$\mathrm{n}$ is the number of individuals;

$y_{i}$ is the observation of the dependent variable for the ith individual; 
$X_{i}=\left(x_{i 1}, x_{i 2}, \ldots, x_{i k}\right)$ is a vector of observations of the independent variables for the ith individual;

$\beta=\left(\beta_{0}, \beta_{1}, \beta_{2}, \ldots ., \beta_{k}\right)$ is a vector of regression coefficients (parameters);

$\varepsilon_{i}$ is a random error component.

The Statistical Package for Social Sciences (SPSS) version 19.0 for Windows (SPSS Inc., Chicago, IL) was used to perform multiple linear regression analysis and correlations.

\section{Results and discussion}

Table 2 shows the descriptive statistics for all variables observed in the five regions studied. Dispersion parameters (SD and CV) show the heterogeneity of variables within each population, which denotes variability and contributes to representativeness in correlation and predictive model construction studies. Regarding the asymmetry coefficient of the distribution of variables, it can be stated that BL, BV, BLD, and SBL presented symmetrical behavior in all
Regions/Populations, i.e., the mean, median, and mode values for each variable were statistically similar. For the characters BD and SBD, this same pattern was only observed in the regions of Lavras, Alto Paranaíba, and Formosa. Bunch weight (BW) also showed symmetrical behavior in the regions of Federal District, Alto Paranaíba, and Formosa.

Kurtosis evaluates the data distribution dispersion degree (Table 2). Data with Leptokurtic distribution are more concentrated around the mean. In the Mesokurtic case, the data follow the behavior of a normal distribution. Finally, in the case of Platykurtic distribution, the values are more dispersed in relation to the average. According to the results of the kurtosis coefficient, variables $B L, B D, B V, B L D, B S L$, and BSD predominantly showed Platykurtic distribution (with greater data dispersion) regarding the $\mathrm{Re}$ gions/Populations studied. Thus, BW was the only variable that showed Leptokurtic distribution (with the smallest dispersion) as dominant in the Regions analyzed.

Table 2 - Descriptive statistics of variables related to physical characteristics of bunch in Macauba, referring to the five regions studied.

\begin{tabular}{|c|c|c|c|c|c|c|c|c|}
\hline Region & $\begin{array}{c}\text { Statistical } \\
\text { parameters }\end{array}$ & BW & $B L$ & BD & BV & BLD & BSL & BSD \\
\hline \multirow{6}{*}{ Montes Claros } & Mean & 17.35 & 66.50 & 37.50 & 76674.50 & 2530.00 & 4527.50 & 1427.50 \\
\hline & SD & 8.34 & 10.81 & 4.86 & 28967.31 & 680.67 & 1367.15 & 356.58 \\
\hline & CV & $48.1 \%$ & $16.3 \%$ & $13.0 \%$ & $37.8 \%$ & $26.9 \%$ & $30.2 \%$ & $25.0 \%$ \\
\hline & SE & 2.64 & 3.42 & 1.54 & 9160.27 & 215.25 & 432.33 & 112.76 \\
\hline & As & 1.19 & -0.28 & -1.54 & -0.84 & -0.75 & -0.08 & -1.45 \\
\hline & Kurt & 0.25 & 0.32 & 0.24 & 0.42 & 0.38 & 0.34 & 0.25 \\
\hline \multirow{6}{*}{ Lavras } & Mean & 18.22 & 36.00 & 36.00 & 42058.07 & 1360.00 & 1360.00 & 1360.00 \\
\hline & SD & 10.71 & 8.94 & 8.94 & 27991.83 & 643.14 & 643.14 & 643.14 \\
\hline & CV & $58.8 \%$ & $24.8 \%$ & $24.8 \%$ & $66.6 \%$ & $47.3 \%$ & $47.3 \%$ & $47.3 \%$ \\
\hline & SE & 4.79 & 4.00 & 4.00 & 12518.33 & 287.62 & 287.62 & 287.62 \\
\hline & As & 1.74 & 0.34 & 0.34 & 0.90 & 0.63 & 0.63 & 0.63 \\
\hline & Kurt & 0.39 & 0.42 & 0.42 & 0.45 & 0.44 & 0.44 & 0.44 \\
\hline \multirow{6}{*}{ Alto Paranaíba } & Mean & 13.77 & 61.54 & 30.68 & 50616.11 & 1947.50 & 3951.39 & 983.11 \\
\hline & SD & 7.08 & 13.07 & 6.59 & 32917.98 & 804.61 & 1738.95 & 435.42 \\
\hline & CV & $51.4 \%$ & $21.2 \%$ & $21.5 \%$ & $65.0 \%$ & $41.3 \%$ & $44.0 \%$ & $44.3 \%$ \\
\hline & SE & 1.34 & 2.47 & 1.25 & 6220.91 & 152.06 & 328.63 & 82.29 \\
\hline & As & 0.12 & 0.35 & 0.31 & 0.86 & 0.64 & 0.61 & 0.57 \\
\hline & Kurt & 0.26 & 0.23 & 0.33 & 0.19 & 0.19 & 0.20 & 0.31 \\
\hline \multirow{6}{*}{ Federal District } & Mean & 38.17 & 77.64 & 42.09 & 129760.13 & 3493.73 & 6475.82 & 1903.36 \\
\hline & SD & 14.37 & 22.21 & 12.04 & 83586.82 & 1727.55 & 3369.77 & 917.34 \\
\hline & $\mathrm{CV}$ & $37.6 \%$ & $28.6 \%$ & $28.6 \%$ & $64.4 \%$ & $49.4 \%$ & $52.0 \%$ & $48.2 \%$ \\
\hline & SE & 4.33 & 6.70 & 3.63 & 25202.38 & 520.88 & 1016.02 & 276.59 \\
\hline & As & -0.97 & 0.36 & -1.47 & -0.21 & -0.18 & 0.76 & -1.31 \\
\hline & Kurt & 0.29 & 0.33 & 0.31 & 0.38 & 0.36 & 0.35 & 0.33 \\
\hline \multirow{6}{*}{ Formosa } & Mean & 19.10 & 54.44 & 29.33 & 37975.75 & 1608.89 & 3011.11 & 875.11 \\
\hline & SD & 5.86 & 7.26 & 4.06 & 13575.14 & 373.49 & 789.10 & 240.29 \\
\hline & CV & $30.7 \%$ & $13.3 \%$ & $13.8 \%$ & $35.7 \%$ & $23.2 \%$ & $26.2 \%$ & $27.5 \%$ \\
\hline & SE & 1.95 & 2.42 & 1.35 & 4525.05 & 124.50 & 263.03 & 80.10 \\
\hline & As & 0.51 & -0.23 & -0.49 & 0.58 & 0.87 & -0.05 & -0.31 \\
\hline & Kurt & 0.24 & 0.31 & 0.25 & 0.21 & 0.29 & 0.32 & 0.23 \\
\hline
\end{tabular}

SD: Standard deviation; CV: Coefficient of variation; SE: Standard error; As: $2^{\text {nd }}$ Coefficient of asymmetry to Pearson $=($ Symmetric: $-1<$ As $<1$; Positive asymmetry: As > 1; Negative asymmetry: As < -1); Kurt: Kurtosis coefficient = (Leptocurtic: Kurt < 0.263; Mesocurtic: Kurt = 0.263; Platicurtic: Kurt > 0.263); BW: bunch weight $(\mathrm{kg})$; BL: bunch length $(\mathrm{cm})$; BD: bunch diameter $(\mathrm{cm})$; $\mathrm{BV}$ : bunch volume $\left(\mathrm{cm}^{3}\right) ; \mathrm{BLD}^{2} \mathrm{BL}{ }^{*} \mathrm{BD}$; $\mathrm{BSL}=\mathrm{BL} \mathrm{L}^{2} ; \mathrm{BSD}=\mathrm{BD}^{2}$. 
High and positive correlations were found for practically all variables for all populations (105 possible associations), except for $\mathrm{BL} \times \mathrm{BD}, \mathrm{BL} \times \mathrm{SBD}, \mathrm{BD} \times$ SBL, and SBL $\times$ SBD for plants in the Formosa region (Table 3). The variable of interest bunch weight (BW) showed a significant, high, and positive correlation with the other variables for all populations. High degrees of associations were found in the regions of Lavras and Distrito Federal, where the highest correlations were observed for BW $\times$ BV $\left(R^{2}=0.971\right)$ and BW $\times$ BLD $\left(R^{2}=0.974\right)$, respectively (Table 3$)$.

Table 3 - Pearson correlation estimates between the variables observed in Macauba bunches for the five regions evaluated.

\begin{tabular}{|c|c|c|c|c|c|}
\hline Correlated variables & Montes Claros & Lavras & Alto Paranaíba & Federal District & Formosa \\
\hline$B W \times B L$ & $0.798^{*}$ & $0.942^{*}$ & $0.797^{\star}$ & $0.967^{\star}$ & $0.608^{*}$ \\
\hline$B W \times B D$ & $0.745^{\star}$ & $0.942^{*}$ & $0.667^{\star}$ & $0.961^{*}$ & $0.956^{*}$ \\
\hline$B W \times B V$ & $0.841^{*}$ & $0.971^{*}$ & $0.737^{\star}$ & $0.957^{\star}$ & $0.952^{*}$ \\
\hline$B W \times B L D$ & $0.839^{*}$ & $0.959^{*}$ & $0.778^{\star}$ & $0.974^{*}$ & $0.914^{*}$ \\
\hline$B W \times B S L$ & $0.830^{*}$ & $0.959^{*}$ & $0.782^{*}$ & $0.950^{*}$ & $0.604^{*}$ \\
\hline$B W \times B S D$ & $0.764^{*}$ & $0.959^{*}$ & $0.665^{*}$ & $0.962^{*}$ & $0.958^{*}$ \\
\hline$B L \times B D$ & $0.767^{*}$ & $1.000^{*}$ & $0.718^{*}$ & $0.930^{*}$ & $0.456^{\mathrm{ns}}$ \\
\hline$B L \times B V$ & $0.908^{*}$ & $0.991^{*}$ & $0.854^{*}$ & $0.974^{*}$ & $0.717^{\star}$ \\
\hline$B L \times B L D$ & $0.952^{*}$ & $0.997^{*}$ & $0.922^{*}$ & $0.989^{\star}$ & $0.841^{*}$ \\
\hline$B L \times B S L$ & $0.996^{*}$ & $0.997^{*}$ & $0.995^{\star}$ & $0.994^{*}$ & $0.999^{*}$ \\
\hline$B L \times B S D$ & $0.777^{*}$ & $0.997^{*}$ & $0.720^{\star}$ & $0.942^{*}$ & $0.456^{\text {ns }}$ \\
\hline$B D \times B V$ & $0.956^{*}$ & $0.991^{*}$ & $0.941^{*}$ & $0.949^{*}$ & $0.936^{*}$ \\
\hline$B D \times B L D$ & $0.924^{*}$ & $0.997^{*}$ & $0.919^{*}$ & $0.961^{*}$ & $0.859^{*}$ \\
\hline$B D \times B S L$ & $0.798^{*}$ & $0.997^{*}$ & $0.721^{*}$ & $0.899^{*}$ & $0.455^{\text {ns }}$ \\
\hline$B D \times B S D$ & $0.998^{*}$ & $0.997^{*}$ & $0.993^{*}$ & $0.991^{*}$ & $0.998^{*}$ \\
\hline$B V \times B L D$ & $0.992^{*}$ & $0.998^{*}$ & $0.987^{\star}$ & $0.995^{\star}$ & $0.979^{*}$ \\
\hline$B V \times B S L$ & $0.930^{*}$ & $0.998^{*}$ & $0.871^{*}$ & $0.974^{*}$ & $0.722^{*}$ \\
\hline$B V \times B S D$ & $0.965^{\star}$ & $0.998^{*}$ & $0.961^{*}$ & $0.978^{*}$ & $0.942^{*}$ \\
\hline$B L D \times B S L$ & $0.967^{*}$ & $1.000^{*}$ & $0.930^{*}$ & $0.983^{*}$ & $0.844^{*}$ \\
\hline$B L D \times B S D$ & $0.932^{*}$ & $1.000^{*}$ & $0.928^{*}$ & $0.978^{*}$ & $0.862^{*}$ \\
\hline$B S L \times B S D$ & $0.809^{*}$ & $1.000^{*}$ & $0.729^{*}$ & $0.923^{*}$ & $0.460^{\text {ns }}$ \\
\hline
\end{tabular}

*: Significant to Pearson correlation $(\mathrm{p}<0.05)$; BW: bunch weight $(\mathrm{kg})$; BL: bunch length $(\mathrm{cm})$; BD: bunch diameter $(\mathrm{cm})$; $\mathrm{BV}$ : bunch volume $\left(\mathrm{cm}^{3}\right) ; \mathrm{BLD}=\mathrm{BL}{ }^{*} \mathrm{BD} ; \mathrm{BSL}=\mathrm{BL}{ }^{2} ; \mathrm{BSD}=\mathrm{BD}^{2}$.

The variables selected using the stepwise method to construct the five models (BV, BL, BLD, and BSD) (Table 4) were the most correlated with the variable of interest within each region (Table 3). The stepwise method usually selects more than one variable for model building, generating a multiple regression model. However, due to the multicollinearity between the variables, evidenced by the high correlation between them, models with only one variable were generated.

Table 4 - Regression models and respective determination coefficients $\left(R^{2}\right)$ for bunch weight estimation (BW), as a function of selected predictor variables, obtained for the five regions evaluated.

\begin{tabular}{lcc}
\hline Region & Model $(\mathrm{Y}=\mathrm{BW})$ & $\mathrm{R}^{2}$ \\
\hline Montes Claros - MG & $-1.232+0.000242(\mathrm{BV})$ & $0.71^{\star *}$ \\
Lavras - MG & $2.602+0.000371(\mathrm{BV})$ & $0.94^{* *}$ \\
Alto Paranaíba - MG & $-12.799+0.432(\mathrm{BL})$ & $0.64^{\star *}$ \\
Federal District & $9.882+0.008(\mathrm{BLD})$ & $0.95^{\star *}$ \\
Formosa - GO & $-1.35+0.023(\mathrm{BSD})$ & $0.92^{\star *}$ \\
\hline
\end{tabular}

${ }^{* *}$ : Significant to F Test $(\mathrm{p}<0.01)$; BV: bunch volume $\left(\mathrm{cm}^{3}\right) ; \mathrm{BL}$ : bunch length $(\mathrm{cm}) ; \mathrm{BLD}=\mathrm{BL}{ }^{*} \mathrm{BD} ; \mathrm{BSD}=\mathrm{BD}^{2}$. 
After stepwise, the models built for the Lavras, Distrito Federal, and Formosa regions explain over $90 \%$ of the total variance in the prediction of bunch weight, while the models for the Montes Claros and Alto Paranaíba regions explain 71 and 64\%, respec- tively (Table 4). The observed versus estimated BW graphs present the data dispersion in relation to the equation line, showing that the points are closer to the line in models where the coefficient of determination has a higher value (Figure 1,Table 4).
A

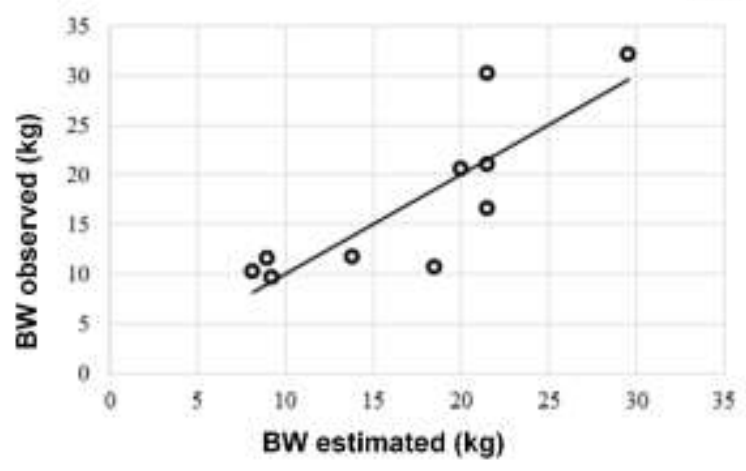

C

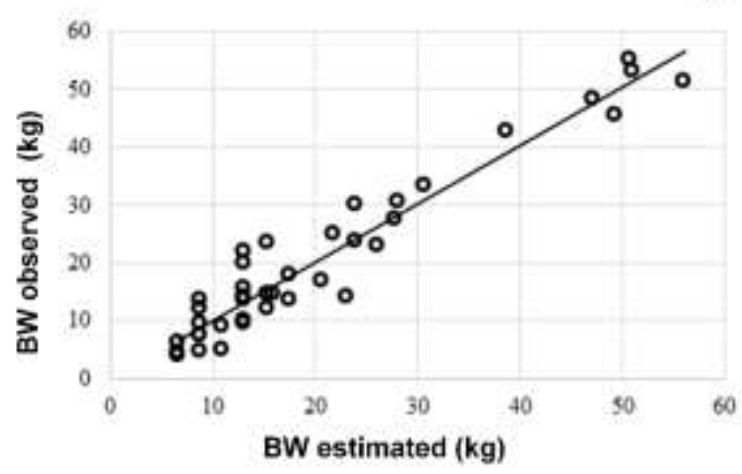

E

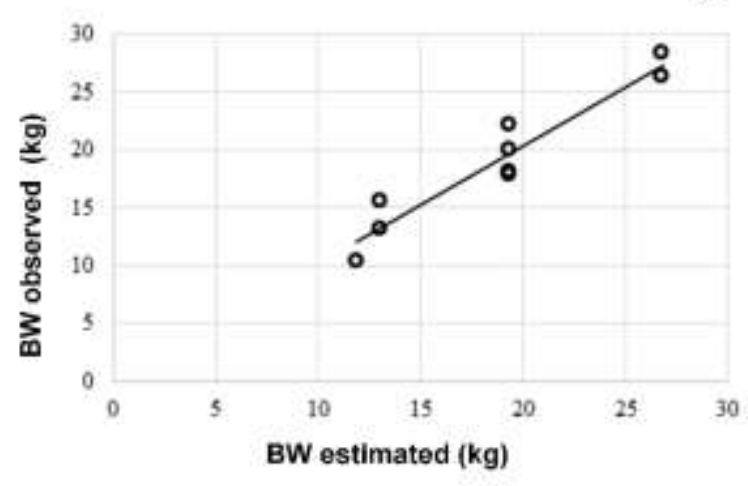

B

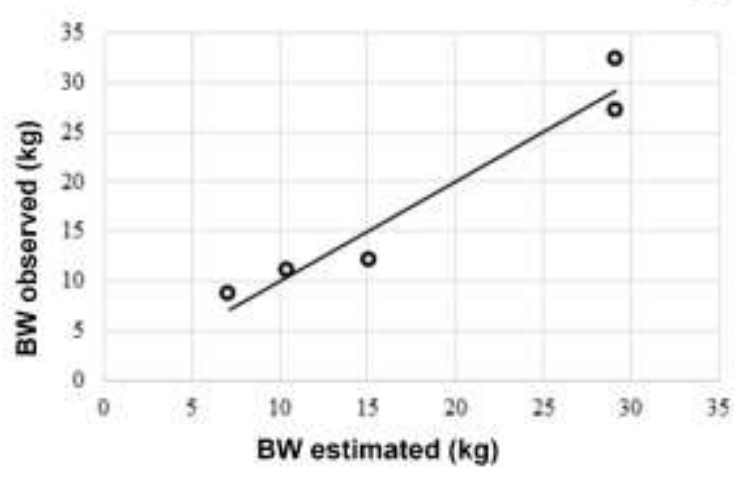

D

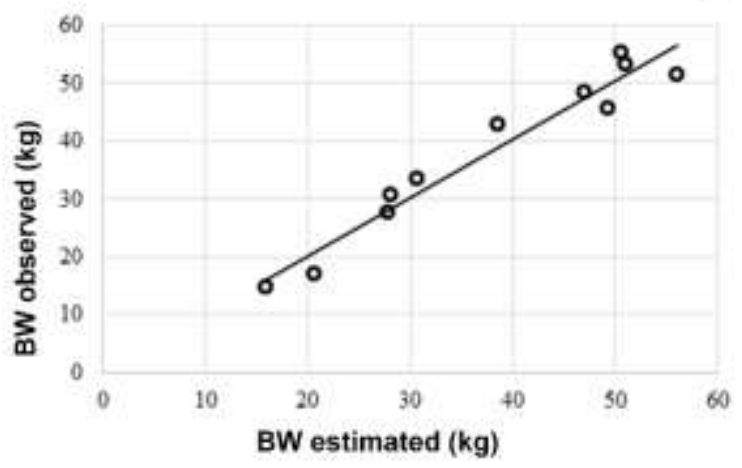

Figure 1 - Scatter plot of bunch weight (BW) values observed versus estimated by constructed models corresponding to each region: (A) Montes Claros, (B) Lavras, (C) Alto Paranaíba, (D) Federal District, and (E) Formosa.

There are no prediction models for characters related to macauba production or yield. There are studies of performance prediction of macauba fruit biomass using Artificial Neural Networks (Castro et al., 2017). In turn, there are some reports analyzing the correlation between physical characters of bunches and fruits, yield components and oil content (Ciconini et al., 2013; Conceição et al., 2015), and correlations between morphological and physiological variables of vegetative development (Domiciano et al., 2015). 
Ciconini et al. (2013) did not find significant correlations between bunch length and the variables bunch weight and number of fruits, and bunch diameter was not considered in the estimates. In Astrocaryum aculeatum G. Meyer, Tucumã, another potential oil source native from the Amazon region, some authors found a positive correlation between bunch weight and bunch length, in addition to a high correlation between bunch weight and bunch diameter (Nascimento et al., 2007). Domingos Neto \& Ferreira (2014) also found high correlations between bunch weight and bunch diameter when studying with Jarina palm tree (Phytlephas macrocarpa Ruiz \& Pavon), showing that diameter is an important component to be tested in models for yield prediction in palm trees in general. Notwithstanding, the models built proved to be suitable for the purposes of the research. Using these models will reduce costs and time, and make plant evaluations less laborious, whether in natural populations or in experimental areas.

\section{Conclusions}

The variables bunch volume, bunch length, bunch length/diameter ratio, and square bunch diameter were effective for constructing the putative models for plants of all studied populations. The models may serve the final purpose of their use in evaluations of natural populations of the respective regions. However, prior validation of these models is necessary to verify their respective effectiveness.

\section{Acknowledgements}

To Finep, CNPq, and Petrobrás, for funding and granting scholarships to undergraduate and postgraduate students.

\section{References}

Abbad G, Torres CV (2002) Regressão múltipla stepwise e hierárquica em Psicologia Organizacional: Aplicações, problemas e soluções. Estudos de Psicologia 7:19-29. dx.doi.org/10.1590/S1413$294 X 2002000300004$

Azevedo RA, Rufino LMA, Santos ACR, Silva LP, Bonfá HC, Duarte ER, Geraseev LC (2012) Desempenho de cordeiros alimentados com inclusão de torta de macaúba na dieta. Pesquisa Agropecuária Brasileira 47(11):1663-1668. 204X2012001100014

Callegari FC (2015) Desenvolvimento e avaliação físico-química e microbiológica de cosméticos para a pele humana contendo óleos de macaúba (Acrocomia aculeata (Jacq.) Lodd. Ex Mart). UFMG (Dissertação de mestrado em Engenharia Química).
Cardoso CAL, Machado ME, Caramão EB (2016) Characterization of bio-oils obtained from pyrolysis of bocaiuva residues. Renewable Energy 91:21-31. doi.org/10.1016/j.renene.2015.11.086

Castro CAO, Resende RT, Kuki KN, Carneiro VQ, Marcatti GE, Cruz CD, Motoyke SY (2017) High-performance prediction of macauba fruit biomass for agricultural and industrial purposes using Artificial Neural Networks. Industrial Crops \& Products 108(2017):806813. dx.doi.org/10.1016/j.indcrop.2017.07.031

Castro Neto MT, Reinhardt DH (2003) Relação entre os parâmetros de crescimento do fruto de manga $\mathrm{CV}$. Haden. Revista Brasileira de Fruticultura 25(1):36-38. dx.doi.org/10.1590/S0100-29452003000100011

César AS, Almeida FA, Souza RP, Silva GC, Atabani AE (2015) The prospects of using Acrocomia aculeata (macaúba) anon-edible biodiesel feedstock in Brazil. Renewable and Sustainable Energy Reviews 49:12131220. doi.org/10.1016/j.rser.2015.04.125

Ciconini G, Favaro SP, Roscoe R, Miranda CHB, Tapeti CF, Miyahira MAM, Bearari L, Galvani F, Borsato AV, Colnago LA, Naka MH (2013) Biometry and oil contents of Acrocomia aculeata fruits from the Cerrados and Pantanal biomes in Mato Grosso do Sul, Brazil. Industrial Crops and Products 45:208-214. doi.org/10.1016/j.indcrop.2012.12.008

Conceição LDHCS, Antoniassi R, Junqueira NTV, Braga MF, Faria-Machado AF, Rogério JB, Duarte ID, Bizzo HR (2015) Genetic diversity of macauba from natural populations of Brazil. BMC Research Notes 8(406):1-9. doi.org/10.1186/s13104-015-1335-1

Domiciano GP, Alves AA, Laviola BG, Conceição LDHCS (2015) Parâmetros genéticos e diversidade em progênies de macaúba com base em características morfológicas e fisiológicas. Ciência Rural 45:15991605. dx.doi.org/10.1590/0103-8478cr20140909

Domingos Neto VC, Ferreira EJL (2014) Biometria de cachos, frutos e sementes da palmeira jarina (Phytlephas macrocarpa Ruiz \& Pavon) oriundos de fragmentos florestais primários e secundários do leste do Acre. Enciclopédia Biosfera 10(19):2765-2775.

Evaristo $A B$, Martino DC, Ferrarez AH, Donato DB, Carneiro ACO, Grossi JAS (2016) Potencial energético dos resíduos do fruto da macaúba e sua utilização na produção de carvão vegetal. Ciência Florestal 26(2):571-577. doi: 10.5902/1980509822757

Fonseca MP, Geraseev LC, Rufino LMA, Garcia IFF, Souza RM, Costa Neto PP (2012) Use of macaúba cake replacing corn on carcass characteristics and body measurements of Santa Inês lambs. Revista Brasileira de Zootecnia 41(5):1231-1235. dx.doi.org/10.1590/S1516-35982012000500021 
Hiane PA, Baldasso C, Marangoni S, Macedo MLR. Chemical and nutritional evaluation of kernels of bocaiuva, Acrocomia aculeata (Jacq.) Lodd. Ciência e Tecnologia de Alimentos 26:683-689. dx.doi.org/10.1590/S0101-20612006000300031

Hiane PA, Ramos Filho MM, Ramos MIL, Macedo MLR (2005) Óleo da polpa e amêndoa de bocaiúva, Acrocomia aculeata (Jacq.) lodd. Caracterização e composição em ácidos graxos. Brazilian Journal of Food Technology 8(3):256-259.

Klingenberg CP, Nijhout HF (2016) Competition among growing organs and developmental control of morphological asymmetry. Proceedings of the Royal Society 265:1135-1139. doi.org/10.1098/rspb.1998.0409

Lanes ECM, Costa PMA, Motoike SY (2014) Brazil promotes aviation biofuels. Nature 511:31. doi.org/10.1038/511031a

Lescano $\mathrm{CH}$, Iwamoto RD, Sanjinez-Argandoña EJ, Kassuya CAL (2015) Diuretic and anti-inflammatory activities of the microencapsulated Acrocomia aculeata (Arecaceae) oil on Wistar rats. Journal of Medicinal Food 18(6):656-662. DOI: 10.1089/jmf.2014.0077

Lopes DC, Steidle Neto AJ, Mendes AA, Pereira DTV (2013) Economic feasibility of biodiesel production from macauba in Brazil. Energy Economics 40:819824. doi.org/10.1016/j.eneco.2013.10.003

Mirth CK, Frankino WA, Shingleton AW (2016) Allometry and size control: what can studies of body size regulation teach us about the evolution of morphological scaling relationships? Current Opinion in Insect Science 13:93-98. doi.org/10.1016/j.cois.2016.02.010

Moraes TJ (2015) Dimensão fractal de espécies arbóreas de ecossistema nativo na região do Pantanal Mato-Grossense. UFMT (Dissertação de mestrado em Física Ambiental).

Morais PLD, Filgueiras HAC, Pinho JLN, Alves RE (2004) Correlação entre variáveis de crescimento do fruto da mangueira 'Tommy Atkins'. Ciência e Agrotecnologia 28(4):743-747. dx.doi.org/10.1590/S141370542004000400003
Nascimento JF, Ferreira EJL, Regiani AM (2007) Parâmetros biométricos dos cachos, frutos e sementes da palmeira Tucumã (Astrocaryum aculeatum G. Meyer), no estado do acre, Brasil. Revista Brasileira de Agroecologia 2(2):1314-1318.

Nass LL, Pereira PAA, Ellis D (2007) Biofuels in Brazil: An overview. Crop Science 47:2228-2237. doi: 10.2135/cropsci2007.03.0166

Ramos MIL, Ramos Filho MM, Hiane PA, Braga Neto JA, Siqueira EMA (2008) Qualidade nutricional da polpa de bocaiúva Acrocomia aculeata (Jacq.) Lodd.. Ciência e Tecnologia de Alimentos 28:90-94. dx.doi.org/10.1590/S0101-20612008000500015

Rufino LMA, Barreto SMP, Duarte ER, Geraseev LC, Santos ACR, Jaruche YG (2011) Efeitos da inclusão de torta de macaúba sobre a população de protozoários ruminais de caprinos. Revista Brasileira de Zootecnia 40(4):899-903. dx.doi.org/10.1590/S151635982011000400026

Santana HMP, Sano EE, Júnior MPO, Lacerda MPC, Malaquias JV (2015) Relação entre atributos físicos e químicos dos solos e a produtividade de capim dourado na região do Jalapão, TO. Revista Brasileira Ciência do Solo 39(4):1172-1180. dx.doi.org/10.1590/01000683rbcs20140364

Silva RAR, Vieira FA, Fajardo CG, Araújo FS (2015) Padrões alométricos da palmeira carnaúba (Copernicia prunifera (Mill.) H.E. Moore). Nativa 3(1):56-58. dx.doi.org/10.14583/2318-7670.v03n01a09

Tabachnick B, Fidell LS (1996) Using multivariate statistics. Harper Collins. 880p.

Vega FVA, Bovi MLA, Spiering SH, Godoy Júnior G (2004) Relações alométricas para estimativa da fitomassa aérea em pupunheira. Horticultura Brasileira 22(1):104-108. dx.doi.org/10.1590/S010205362004000100022

Zucoloto M, Lima JSS, Coelho RI, Xavier AC (2013) Modelos de regressão para estimação da massa do cacho de bananeira cv. Prata anã. Bioscience Journal 29(6):1997-2000. 